\title{
Heavy metal removals from industrial wastewater using modified zeolite: study the effect of pre-treatment
}

\author{
Ali Mohammed Salih ${ }^{1}$, Craig Williams ${ }^{2}$, Polla Azad Khanaqa1 \\ 1Head of Geology Department, Kurdistan Institution for Strategic Studies and Scientific Research \\ 2 Faculty of Science and Engineering, University of Wolverhampton \\ 3 Head of institution, Kurdistan Institution for Strategic Studies and Scientific Research
}

\section{Article Info}

Received: April, 2019

Revised:April,2019

Accepted:May,2019

\section{Keywords}

Adsorption, natural zeolite, modified zeolite, kinetic

study, hydrothermal

treatment, chemical

treatment.

\section{Corresponding Author}

shwangeology@yahoo.com.

\begin{abstract}
Pre-treatment processes were performed in order to investigate the behavior of modified clinoptilolite (natural zeolite) as adsorbents and understand the removal mechanisms involved in the adsorption process. The pre-treatment of clinoptilolite is carried out to increase the metal removal efficiency from solution. For this purpose, both hydrothermal and chemical pre-treatment of clinoptilolite were carried out in order to investigate whether pre-treatment could increase the adsorption capacity of clinoptilolite. The zeolite samples were characterized by using different analytical techniques such as Scanning Electron Microscopy (SEM), Energy Dispersive Spectroscopy (EDS), X - Ray Diffraction (XRD), X - Ray Fluorescence (XRF), Thermogravimetric Analys is (TGA), Fourier Transform Infrared (FT-IR) Spectroscopy and Inductively Coupled Plasma-Optical Emission Spectrometers (ICP-OES). The thermal pretreatment process of clinoptilolite was carried out by heating clinoptilolite samples in a furnace for 30 minutes under a slow heating rate of 200, 400 and $600^{\circ} \mathrm{C}$. The chemical pre-treatment of the clinoptilolite were carried out by mixing clinoptilolite sample with $200 \mathrm{ml}$ of $0.5 \mathrm{M} \mathrm{NaCl}$. Then $4 \mathrm{~g}$ of modified clinoptilolite samples were in contact with $100 \mathrm{ml}$ of multi- component solutions for 360 minutes. The data obtained from the kinetic adsorption tests the shows that the efficiency of $\mathrm{Cu} 2+, \mathrm{Fe} 3+, \mathrm{Co} 2+$ and $\mathrm{Zn} 2+$ metal ions removal was enhanced with the application of pre-treatments.
\end{abstract}

\section{Introduction}

Zeolites are an inorganic microporous crystalline solid substance contains silicon, aluminium and oxygen in its framework [1, 2]. Usually, large cavities and channels inside the zeolite framework are contain water molecules forming hydration spheres around exchangeable cationic. Clinoptilolite can be modified using thermal or chemical treatment separately or can be treated as a combined process [3, 4, 5, 6 and 7]. Thermal treatment depends on the zeolite structure and rate of temperature used in the processes. Thermal treatment result in improve pore volume by removing water molecules and hydroxyl group present in cavities and channels of the clinoptilolite framework which contributes $10-$ $25 \%$ to the total mass of clinoptilolites [4]. To determine the adsorption capacity of clinoptilolite in wastewater treatment, it is important to study the dehydration and 
dehydroxylation processes with structural stability of natural zeolitic materials.

Clinoptilolite can be chemically modified by using various type of inorganic salts (e.g. $\mathrm{NaCl}$, $\mathrm{CaCl} 2, \mathrm{BaCl} 2, \mathrm{NH} 4 \mathrm{Cl}, \mathrm{FeCl} 3$ ) to activate the zeolite and increase its efficiency in water treatment [8, 9, 10, 11, 12 and 13]. Among those inorganic salts, $\mathrm{NaCl}$ solution is the most commonly used as a pre-treatment agent for the conversion of clinoptilolite to hormonic or near harmonic form [14, 15, 16 and 17]. Using $\mathrm{NaCl}$ solution result in cation migration from clinoptilolite framework and it is well-known as an effective technique to increase ion exchangers overall cation exchange capacity for water treatment applications [18]. Previous studies showed that the most widely used concentration ranges are 0.5-2.0 $\mathrm{M} \mathrm{NaCl}[14,19,20,21$ and 22].

Zeolites can be used in various industrial applications due to its high cation-exchange ability and molecular sieve and catalysis properties. The adsorption and ion exchange process are the most widely used techniques that have attracted increasing interest in different companies [17, 23]. Different type of synthetic zeolites were developed such as (4A, mordenite, $\mathrm{X}, \mathrm{Y}$ zeolites, etc.) which they have higher adsorption capacities and higher performances, compared to clinoptilolites, but they are usually very expensive $[17,23]$. In the meantime, modified zeolites have been developed that can be rated as having a median adsorption capacity, while they do not cost as much as synthetic zeolite and have a better adsorption capacity than clinoptilolite [24].

Experiments were carried out in order to investigate the impact of pre-treatment on the efficiency of zeolite for the removal of $\mathrm{Cu} 2+$, $\mathrm{Fe} 3+, \mathrm{Pb} 2+$ and $\mathrm{Zn} 2+$ ions from synthetic industrial wastewater.

\section{Experimental procedure}

In this study clinoptilolite was used. The natural clinoptilolite was mined in Anaconda and supplied by the Anaconda mining company, Denver Colorado, USA it is $97 \%$ pure. The clinoptilolite samples were used as received without any modification from their natural state, unless stated. Kinetic studies were performed in order to investigate the behaviour of adsorbents and understand the removal mechanisms involved in the adsorption process. The present work involves the study of the removal of $\mathrm{Cu} 2+$, $\mathrm{Fe} 3+, \mathrm{Pb} 2+$ and $\mathrm{Zn} 2+$ from synthetic metal solutions using natural zeolite. Laboratory experiments were cured out at university of Wolverhampton and kinetic test used to investigate the efficiency of adsorbents in the uptake of heavy metals from industrial wastewater.

\subsection{Thermal pre-treatment process}

The thermal pre-treatment process of clinoptilolite was performed by heating clinoptilolite samples in a furnace for 30 minutes under a slow heating rate of 200,400 and $600^{\circ} \mathrm{C}$ to avoid destroy the zeolite structure. Then $4 \mathrm{~g}$ of the thermally modified clinoptilolite samples were in contact with $100 \mathrm{ml}$ of multi- component solutions. Agitation was carried out in a beaker using a stirrer at a speed of $150 \mathrm{rpm}$ for 360 minutes at room temperature. The $\mathrm{pH}$ of the solution was adjusted to $4 \pm 0.1$.

\subsection{Chemical pre-treatment process}

The chemical pre-treatment of the clinoptilolite were carried out by placing clinoptilolite sample with $200 \mathrm{ml}$ of $0.5 \mathrm{M} \mathrm{NaCl}$. The zeolite sample was agitated in a beaker using a stirrer at a speed of $150 \mathrm{rpm}$ for 24 hours at room temperature. Thereafter the sample was rinsed three times in ample deionised water for a total period of 15 minutes and put in an oven to be dried at $100^{\circ} \mathrm{C}$.

Then $4 \mathrm{~g}$ of chemically modified clinoptilolite samples were in contact with $100 \mathrm{ml}$ of multicomponent solutions for 360 minutes. The agitation speed applied was $150 \mathrm{rpm}$ at room temperature. The $\mathrm{pH}$ of the solution was adjusted to $4 \pm 0.1$. For successful modification $0.5 \mathrm{M}$ $\mathrm{NaCl}$ solutions were used to modify the clinoptilolite. Washing the zeolite samples after the pre-treatment process using deionised water is essential in order to remove excess $\mathrm{NaCl}$ entrapped within the zeolite structure [25].

\section{Results and discussion}

\subsection{Scanning Electron Microscopy (SEM)}

The surface morphologies of the different clinoptilolite samples before and after modification were analysed. Fig. 1(a,b) show the micrographs of the "as received" clinoptilolite samples. The images were taken under the 
following SEM analytical conditions: EHT $=10.00 \mathrm{kV}$ and Signal A = SE1, WD $6.5 \mathrm{~mm}$ at a magnification of 1000x, 5000x. The micrographs clearly show that the clinoptilolite structure contains a number of different diameter size macro-pores $(1 \mu \mathrm{m} \leq \mathrm{d} \leq 3 \mu \mathrm{m})$.

The effect of chemical pre-treatment was also analysed (Fig. 2) under the following SEM analytical conditions: EHT $=10.00 \mathrm{kV}$, Signal A $=\mathrm{SE} 1, \mathrm{WD} 6.5 \mathrm{~mm}$ at a magnification of $1000 \mathrm{x}$ and 5000x. The micrographs below show a clean surface and well defined crystal structures of clinoptilolite.

Fig.3 (a) shows that there is not significant change in the microstructure of thermally treated clinoptilolite at $200{ }^{\circ} \mathrm{C}$. The images were taken under the following SEM analytical conditions: EHT $=10.00 \mathrm{kV}$, Signal A = SE1, WD $6.5 \mathrm{~mm}$ at a magnification of 5000x. The SEM figures show some well-defined zeolite crystals but the surface of the crystals seem to have considerably decomposed due to direct heating at $400{ }^{\circ} \mathrm{C}$; this can be noticed in Fig.3 (b). The macro-pores on the clinoptilolite structure also seem to have slightly collapsed and the distinct crystal structures of clinoptilolite have disappeared. This was lead to appearance more solid less porous surface on the clinoptilolite structure.

Fig.4 shows the clinoptilolite sample that was exposed to extreme thermal conditions. The images were taken under the following SEM analytical conditions: EHT $=10.00 \mathrm{kV}$, Signal A $=\mathrm{SE} 1$, WD $6.0 \mathrm{~mm}$ at a magnification of 3000x. The sample heated to $600{ }^{\circ} \mathrm{C}$ shows how thermal radiation has had a negative impact on the structure of clinoptilolite. As the heating rate increased, the structure became more distorted and the macro-pores on the clinoptilolite structure have collapsed.

\subsection{Energy dispersive spectroscopy (EDS)}

EDS is an analytical technique that was used to identify the elemental composition and chemical characterization of clinoptilolite. An electron beam was randomly directed onto different parts of the clinoptilolite samples in order to get a more accurate analysis Fig.5. The main elements and their corresponding oxides were determined by EDS.

The results of the EDS analysis also shows that the predominant exchangeable cations in the clinoptilolite structure were found to be $\mathrm{Na}$, $\mathrm{Mg} 2+, \mathrm{K}+$ and $\mathrm{Ca} 2+$ (Table 1).

\begin{tabular}{lcccc} 
Element & $\begin{array}{c}\mathbf{N a}_{\mathbf{2}} \mathbf{O} \\
\mathbf{\%}\end{array}$ & $\begin{array}{c}\mathbf{M g O} \\
\mathbf{\%}\end{array}$ & $\begin{array}{c}\mathrm{Al}_{\mathbf{2}} \mathbf{O}_{\mathbf{3}} \\
\mathbf{\%}\end{array}$ & $\begin{array}{c}\mathbf{S i O}_{\mathbf{2}} \\
\mathbf{\%}\end{array}$ \\
\hline EDS & 3.98 & 0.69 & 14.23 & 29.22 \\
XRF & 4.12 & 0.89 & 16.53 & 37.97 \\
Element & $\begin{array}{c}\mathbf{K}_{\mathbf{2}} \mathbf{O} \\
\mathbf{\%}\end{array}$ & $\begin{array}{c}\mathbf{C a O} \\
\mathbf{\%}\end{array}$ & $\begin{array}{c}\mathbf{T i O}_{\mathbf{2}} \\
\mathbf{\%}\end{array}$ & $\begin{array}{c}\mathbf{F e}_{\mathbf{2}} \mathbf{O}_{\mathbf{3}} \\
\mathbf{\%}\end{array}$ \\
\hline EDS & 2.39 & 0.84 & 0.06 & 0.54 \\
XRF & 2.12 & 0.96 & 0.06 & 0.74 \\
\hline
\end{tabular}

\subsection{X-Ray Fluorescence (XRF)}

XRF analytical analysis of the clinoptilolite samples also was carried out to determine the elemental composition of the samples. The results of the XRF analysis are presented in Table 1. The result shows that $\mathrm{SiO} 2, \mathrm{Al} 2 \mathrm{O} 3$, $\mathrm{Na} 2 \mathrm{O}$ and $\mathrm{K} 2 \mathrm{O}$ are main components of clinoptilolite but higher rate compared to EDS analysis result. The results of the XRF analysis are similar to EDS analysis result which showed that the predominant exchangeable cations in the clinoptilolite structure were $\mathrm{Na}+\mathrm{Mg} 2+, \mathrm{K}+$ and $\mathrm{Ca} 2+$.

\subsection{X - Ray Diffraction (XRD) results}

X-ray diffraction (XRD) analytical technique was used for phase identification of the clinoptilolite. The procedure was carried out and data were collected in the range 0-50 degrees, with a scanning step of ${ }^{\circ} 2 \theta$. The crystalline patterns were compared with the standard line patterns from the powder diffraction file database supplied by the International Centre for Diffraction Data (ICDD). Thus the XRD result showed that the sample contained clinoptilolite in the majority (Fig. 6).

\subsection{Thermogravimetric Analysis (TGA) result}

Thermal analysis methods were used to gain information about the mass loss change and structural stability of clinoptilolite of. The results 
obtained from the TG/DTG analysis clearly show that the zeolite structure was stable up to $750{ }^{\circ} \mathrm{C}$ and dehydration process appeared up to $400 \mathrm{oC}$ continually this is an agreement with is the result presented by Breck (1974). Fig.7. shows the dehydration and dehydroxylation process of clinoptilolite and their mass loss rate (13 wt. \%.). Results obtained from TGA/DTG show that, clinoptilolite samples were continually losing weight after heating up to $900{ }^{\circ} \mathrm{C}$ (Fig. 8). The main reasons of this are due to dehydration and dehydroxylation processes. According to Perraki and Orfanoudaki (2004) weight losses at 20-100 ${ }^{\circ} \mathrm{C}$ and $100-200{ }^{\circ} \mathrm{C}$ are due to hygroscopic water and loosely bonded water, respectively [2,27 and 28]. Then dehydroxylation took place in the range 400-600 ${ }^{\circ} \mathrm{C}$ [29]. Kurkuna et al. (2006) reported two forms of water molecules and hydroxyl groups existing in the structure of silicate minerals such as clinoptilolite [30]. The total loss calculated from the thermogravimetric analysis was $13 \mathrm{wt}$. \%. Similar values were obtained by other authors [30, 31, 32 and 27].

\subsection{Fourier Transform Infrared (FT-IR) Spectroscopy results}

FT-IR Spectroscopy technique was used to obtain an infrared spectrum of absorption of clinoptilolite. Only the $1200-400 \mathrm{~cm}-1$ region was investigated; this is where the all spectra showed remarkable changes. A broad band between 3500 and $3700 \mathrm{~cm}-1$ is indicative of the presence of $\mathrm{OH}$ groups on the clinoptilolite surface. In the $\mathrm{OH}$ stretching region, infrared spectra of zeolites provide a wealth of information on hydroxyl groups attached to zeolite structures (Li, 2005). FT-IR results demonstrate (Fig. 9) that zeolites are significantly hydrated. The bands, which were located at $3444 \mathrm{~cm}-1$ refer to $\mathrm{OH}$ group and $1637 \mathrm{~cm}-1$ refer to $\mathrm{H} 2 \mathrm{O}$ molecules associated with $\mathrm{Na}$ and $\mathrm{Ca}$ in the channels and cages in the of the zeolite structure [33]. The $1015 \mathrm{~cm}-1$ band corresponds to asymmetric stretching vibration modes of internal Si-O-Si or Si-O-Al bonds. The 796 and $448 \mathrm{~cm}-1$ bands indicative of the stretching vibration modes of $\mathrm{Si}-\mathrm{O}-\mathrm{Si}$ or $\mathrm{Si}-\mathrm{O}-\mathrm{Al}$ bonds groups and the bending vibrations of $\mathrm{Si}-\mathrm{O}$ bonds, respectively [34]. These results are similar as those obtained by other authors [35, 27].

\subsection{Inductively Coupled Plasma-Optical} Emission Spectrometers (ICP-OES) results

The heavy metal ion concentrations in the waste water solution were determined using ICP-OES. Results shows the behavior of adsorbents and the pre-treatment factor that affect the rate of adsorption and maximum effective capacity of clinoptilolite towards $\mathrm{Fe} 3+, \mathrm{Cu} 2+, \mathrm{Pb} 2+$ and $\mathrm{Zn} 2+$ ions removal. Every hour $15 \mathrm{ml}$ of the sample was taken for metal ion concentration analysis using the ICP-OES. Microsoft office excel were used for data interpretation. After a mathematic calculation the results were presented either by plotting a chart or presenting data in a table.

The data obtained from the kinetic adsorption tests were used to determine the removal capacity, qe $(\mathrm{mg} / \mathrm{g})$ of the different adsorbents using the following equation:

$$
q e=(\mathrm{Co}-\mathrm{Ce}) \mathrm{XV} / \mathrm{m}
$$

The percentage removal of metal ions from solution was also determined using the equation below:

$$
\begin{array}{r}
\text { Percentage Adsorbed (\% removal) qe } \\
=\{(C o-C e) X 100\} / C o
\end{array}
$$

where,

qe amount of adsorbate adsorbed per unit weight of adsorbent $(\mathrm{mg} / \mathrm{g})$

$\mathrm{Co}$ and $\mathrm{Ce}$ are the initial and final metal ion concentrations in solution $(\mathrm{mg} / \mathrm{l})$ respectively, $\mathrm{V}$ is the solution volume (l) and $\mathrm{m}$ is the weight of the zeolite used (g).

The results of the effect of the pre-treatment on the removal of the cations from the solution are shown in Fig.10. Although the thermal treatment process can affect the adsorption capacity, mostly up to $200 \mathrm{oC}$, as the temperature rate increases more, there is a decrease in the level of the effect of the thermal treatment process on adsorption and the adsorption process gets slower.

It was observed that the thermal treatment samples at $200^{\circ} \mathrm{C}$ adsorbed more metal ions of $\mathrm{Cu} 2+, \mathrm{Fe} 3+, \mathrm{Pb} 2+$ and $\mathrm{Zn} 2+$ ions from solution, around $\% 50$ better than the thermal treatment samples at $400^{\circ} \mathrm{C}$ adsorbed less metal ions as shown in Fig.10. Also, the rate of adsorption by calcined zeolite up to $200 \mathrm{oC}$ was $\% 10$ better compared to the untreated zeolite, but the efficiency decreased when zeolite was treated at very high temperatures. 
The increase in the efficiency of heavy metal removal from solution as a result of thermal treatment may be due to the removal of water and hydroxyl groups from the clinoptilolite structure. This removal of water and hydroxyl group results in a change in the surface area of the samples and also leaves the channels more vacant and available. Hence the adsorption capacity is improved since the heavy metal ions had better access to exchangeable sites within the clinoptilolite [36, 37]. However, the decline in the efficiency for zeolite treated at very high temperatures was related to the possible collapse of the zeolite structure and the loss of porosity, which reduced the activated surface area [37].

The adsorption capacity as a result of the chemical treatment processes was higher compared to the untreated zeolite or thermal pretreatment zeoliteas shown in Fig 7 and 8. This may be due to decationization process which is exchange of $(\mathrm{H}+$ or $\mathrm{Na}+)$ from solution with exchangeable cations $(\mathrm{Na}+, \mathrm{K}+, \mathrm{Ca} 2+, \mathrm{Mg} 2+)$ from the zeolite framework which they can be easily removed.

\section{Conclusion}

-The removal efficiency of $\mathrm{Cu} 2+, \mathrm{Fe} 3+, \mathrm{Pb} 2+$ and $\mathrm{Zn} 2+$ ions from synthetic industrial wastewater, was enhanced with the application of pre-treatments.

-Application of any temperature above $200{ }^{\circ} \mathrm{C}$ is not suitable in thermal treatment process. Further thermal treatment may lead to lose some porosity and decomposition of some crystalline structure due to.

-Modified zeolites have high adsorption capacities for removal of heavy metals from solutions and can reach adsorption equilibrium level in short periods of time while pre-treatment process applied.

- The adsorption capacity as a result of the chemical treatment processes was higher compared to the untreated zeolite or thermal pretreatment zeoliteas.

\section{References:}

[1] Mortier, W.J. (1982) Structure Commission of the International Zeolite Association, Compilation of extra framework sites in zeolites. Scientific Ltd: Butterworth.

[2] Dyer, A. (1988) An introduction to zeolite molecular sieves. GB: John Wiley\& Sons Ltd.
[3] Günay A, Arslankaya E, Tosun İ. (2007) Lead removal from aqueous solution by natural and pretreated clinoptilolite: adsorption equilibrium and kinetics. Journal of Hazardous Materials. 146(1), pp.362-371.

[4] Margeta, K., Logar, N.Z., Šiljeg, M. and Farkaš, A.(2013) Clinoptilolites in Water Treatment - How Effective is Their Use, Chapter 5 [online] [accessed on 08 November 2016] available at: <http://www.intechopen.com/books/water-

treatment/natural-zeolites-in-water-treatment-howeffective-is-their-use>.

[5] Inglezakis VJ, Papadeas CD, Loizidou MD, Grigoropoulou HP (2001) Effects of pretreatment on physical and ion exchange properties of natural clinoptilolite. Journal of Environmental Technology.22(1), pp.75-82.

[6] Babak K, Rahim AA, Wahid SA, Balasundram SK, Afyuni M. (2013) Sorption and desorption of zinc by clinoptilolite and clinoptilolite-tridymite. Malaysian journal of Soil Science. 17, pp.69-83.

[7] Wang X, Ozdemir O, Hampton MA, Nguyen AV, Do DD.(2012) The effect of zeolite treatment by acids on sodium adsorption ratio of coal seam gas water. Water Research. 46(16), pp.5247-5254. 10.1016/j. watres.2012.07.006.

[8] Oliveira CR, Rubio J (2007) New basis for adsorption of ionic pollutants onto modified zeolites. Journal Mineral. Engineering 20(6), pp. 552-558.

[9] Ortega EA, Cheeseman Ch, Knight J, Loizidou M (2000) Properties of alkali-activated clinoptilolite. Cement.Concrete.Research. 30(10) pp. 1641-1646.

[10] Dávila-Jiménez MM, Elizalde-González MP, Mattusch J, Morgenstern P, Pérez-Cruz MA, ReyesOrtega Y, Wennrich R, Yee-Madeira H (2008) In situ and ex situ study of the enhanced modification with iron of clinoptilolite-rich zeolitic tuff for arsenic sorption from aqueous solutions. Journal of Colloid and Interface Science. 322(2),pp.527-536.

[11] Šiljeg M, Cerjan Stefanović Š, Mazaj M, Novak Tušar N, Arčon I, Kovač J, Margeta K, Kaučič V, Zabukovec Logar N (2009) Structure investigation of As(III)- and As(V)-species bound to Fe-modified clinoptilolite tuffs, Microporous and Mesoporous Materials. 118(13), pp.408-415.

[12] Kumar, J.V. and Hayashi, S. (2009) Modification on natural clinoptilolite zeolite for its $\mathrm{NH} 4+$ retention capacity. Journal of Hazardous Materials. 169(1-3), pp. 29-35.

[13] Li, G. (2005) FT-IR studies of zeolite materials: characterization and environmental applications." $\mathrm{PhD}$ diss., University of Iowa. $\langle$ http://ir.uiowa.edu/etd/96>.

[14] Culfaz, M. and Yagiz, M. (2004) Ion exchange properties of natural clinoptilolite: lead-sodium and cadmium-sodium equilibria. Separation and Purification Technology, 37(2), pp. 93-105. 
[15] Bektas, N. and Kara, S. (2004) Removal of lead from aqueous solutions by natural clinoptilolite: equilibrium and kinetic studies. Separation and Purification Technology, 39, pp.189 - 200.

[16] Semmens, M. and Martin, W. (1988) The influence of pretreatment on capacity and selectivity of clinoptilolite for metal ions. Water Research, 22, pp. $537-542$.

[17] Inglezakis, V.J. and Grigoropoulou, H. (2004) Effects of operating conditions on the removal of heavy metals by zeolite in fixed bed reactors. Journal of Hazardous Materials, 12, pp. 37-43.

[18] Santiago O., Walsh K., Kele,B., Gardner,E. and Chapman J. (2016) Novel pre-treatment of zeolite materials for the removal of sodium ions: potential materials for coal seam gas co-produced wastewater. Published online $2016 \quad$ May 10.[ https://www.ncbi.nlm.nih.gov/pmc/Springerplus ]

[19] Ouki S.K., Cheeseman C. and Perry R. (1994) Clinoptilolite utilisation in pollution control: a review of applications to metal' effluents. Journal of Chemical Technology and Biotechnology, 59, pp.121 $-126$.

[20] Curkovic, L., Cerjan-Stefanovic, S. and Filipan, T. (1997) Metal ion exchange by natural and modified zeolites. Water Research, 31(6), pp. 1379 - 1382.

[21] Cincotti, A., Mameli, A., Locci, M. A., Orru, R. and Cao, G. (2006) Heavy metal uptake by Sardinian clinoptilolites: Experiment and modelling. Industrial and Engineering Chemistry Research. 45, pp.10741084.

[22] Langella, A., Pansini, M. Cappelletti, P., de Gennaro, B., de Gennaro, M. and Colella, C. (2000) $\mathrm{NH} 4+, \mathrm{Cu} 2+, \mathrm{Zn} 2+, \mathrm{Cd} 2+$ and $\mathrm{Pb} 2+$ exchange for $\mathrm{Na}+$ in sedimentary clinoptilolite, North Sardinia, Italy. Microporous and Mesoporous Material, 37, pp. 337-343.

[23] Pandey, P., Sambi, S.S., Sharma, S.K. and Singh, S. (2009) Batch Adsorption Studies for the Removal of $\mathrm{Cu}$ (II) Ions by ZeoliteNaX from Aqueous Stream. Proceedings of the World Congress on Engineering and Computer Science, I, San Francisco, USA

[24] Colella, C. (2007) Environmental applications of natural zeolitic materials based on their ion exchange properties. Natural Microporous Materials in Environmental Technology, 362, pp 207-224.

[25] Ouki, S.K. and Kavannagh, M. (1999) Treatment of metals contaminated wastewaters by use of clinoptilolites. Water Science and Technology, 39(1011), pp.115 - 122 .

[26] Breck, D.W. (1974) Zeolite Molecular Sieves: Structure, Chemistry and Use, 1st ed. John Wiley: New York.

[27] Perraki, T. and Orfanoudaki, A. (2004) Mineralogical study of zeolites from Pentalofos area. Applied Clay Science, 25, pp.9-6.
[28]Gottardi, G. and Galli, E. (1985) Clinoptilolites. Berlin Heidelberg: Springer Verlag.

[29] Ribero, F.R, Rodrigues,A.E., Rollmann, L.D. and Naccache, C. (1984) Zeolite:Science and Technology. Lancaster: Martinus Nijhoff.

[30] Korkuna, O., Leboda, R., Skubiszewska-Ziemba, J., Vrublevska, T., Gunko, V.M. and Ryczkowski, J. (2006) Structural and physicochemical properties of clinoptilolites: clinoptilolite and mordenite. Microporous and Mesoporous Materials, 87, pp. 243.

[31] Al-Dwairi, R.A. (2009) The Use of Expendable Local Zeolite Deposits for NH4 Removal in Municipal Wastewater. Jordan Journal of Civil Engineering, 3(3), pp. 256 -263.

[32] Ugal, J.R., Hassan, K.H. and Ali, I.H. (2010) Preparation of type 4A zeolite from Iraqi kaolin: Characterization and properties measurements. Journal of the Association of Arab Universities for Basic and Applied Sciences, 9, pp. 2-5.

[33] Wilson, M.J. (1994) Clay Mineralogy: Spectroscopic and Chemical Determinative Methods. Chapman and Hall: New York, 1994.

[34] Tanaka, H., Yamasaki, N., Muratani, M.and Hino, R. (2003) Structure and formation process of (K, Na)- clinoptilolite. Materials Research Bulletin, 38, PP.713.

[35] Olad, A. and Naseri, B. (2010) Preparation, characterization and anticorrosive properties of a novel polyaniline/clinoptilolite nanocomposite. Progress in Organic Coatings, 67, pp.233 -238.

[36] Turner, M.D., Laurence, R.L., Conner, W.C. (2000) Microwave radiation's influence on sorption and competitive sorption of zeolites. AIChE Journal, 46 (4), pp. 758 - 768.

[37] Tatsuo, O. and Nagae M., (2003) Quick activation of optimized zeolites with microwave heating and utilization of zeolite for re-useable desiccant. Journal of Porous Materials, 10, pp.1 


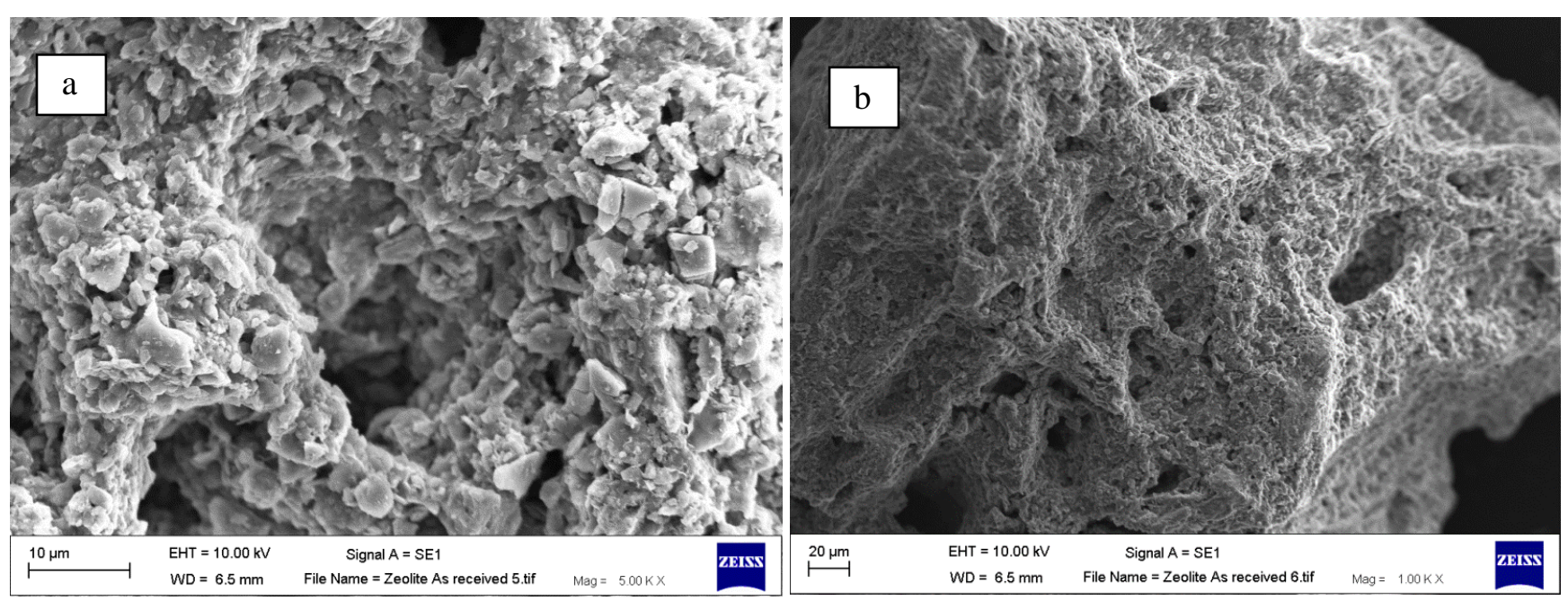

Fig. 1. Showing the SEM micrograph of as-received clinoptilolite at a magnification of: (a) 5000x and (b) $1000 \mathrm{x}$.
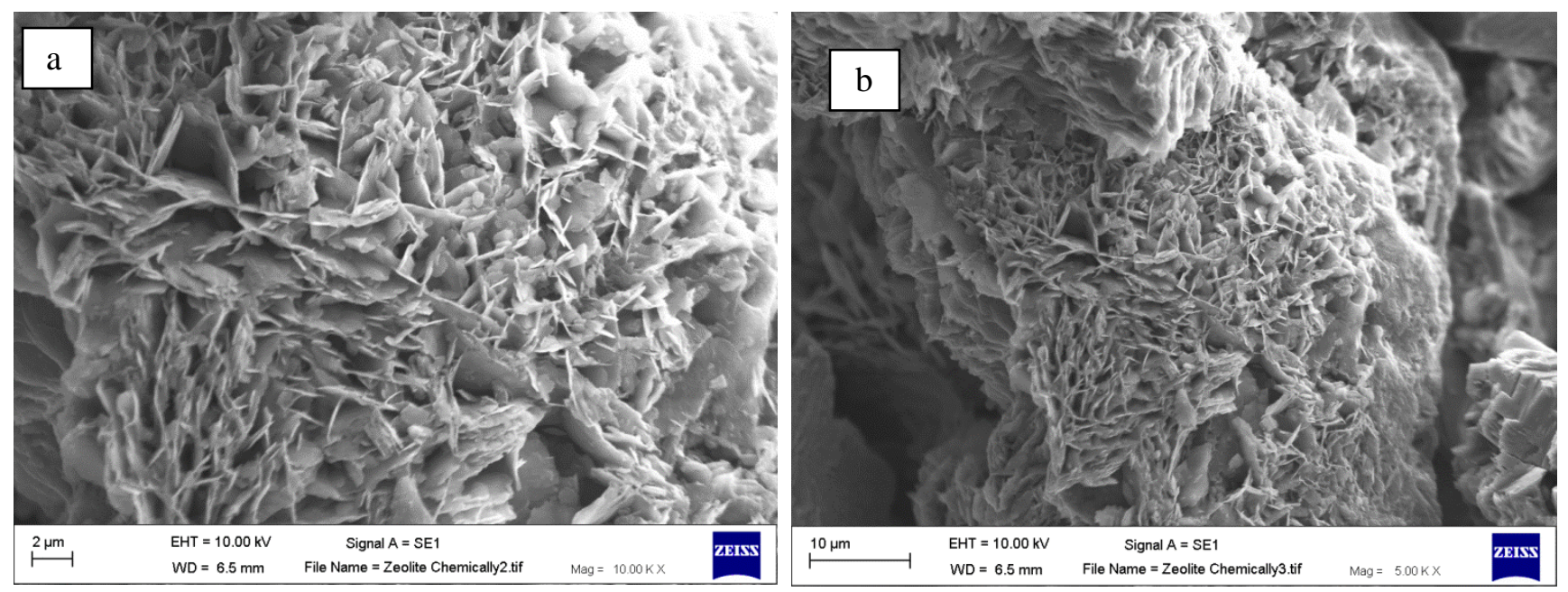

Fig. 2. SEM micrographs of chemical pre-treatment of clinoptilolite at different magnifications: (a) 10000x and (b) 5000x.
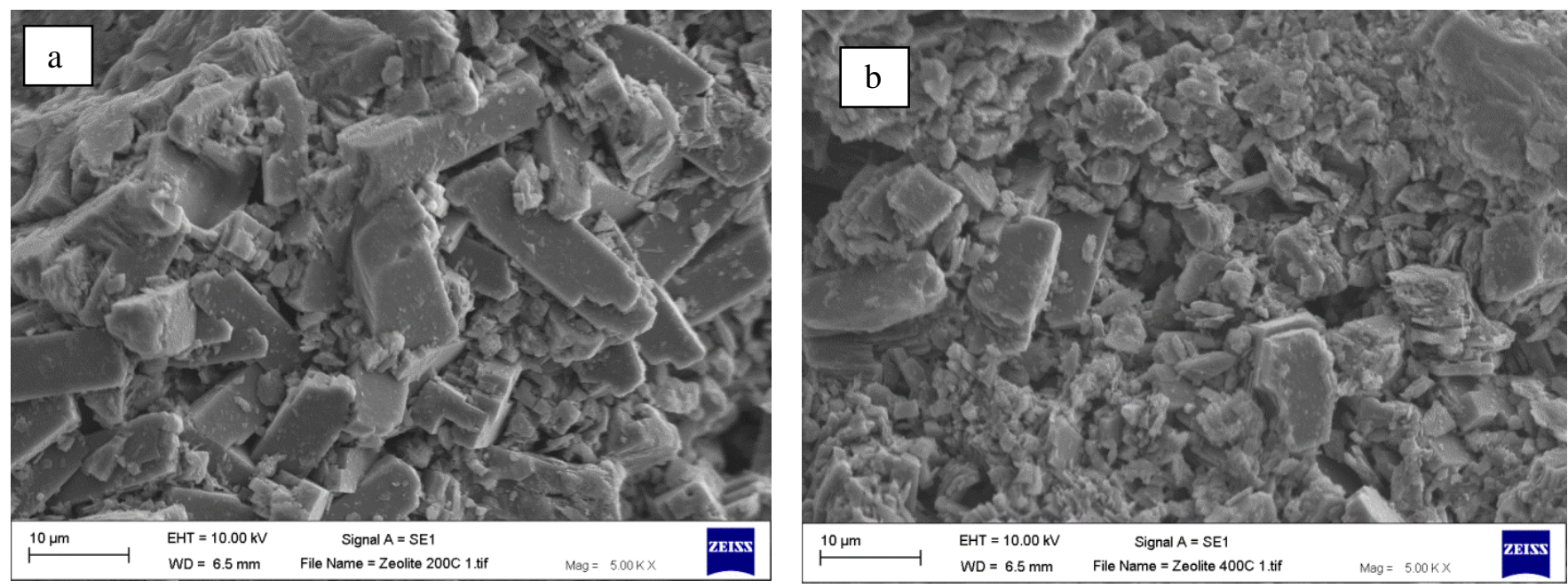

Fig. 3. SEM microstructure of thermally pre-treated clinoptilolite in a muffle furnace at (a) $200{ }^{\circ} \mathrm{C}$ (b) $400{ }^{\circ} \mathrm{C}$, at a magnification of $5000 \mathrm{x}$. 


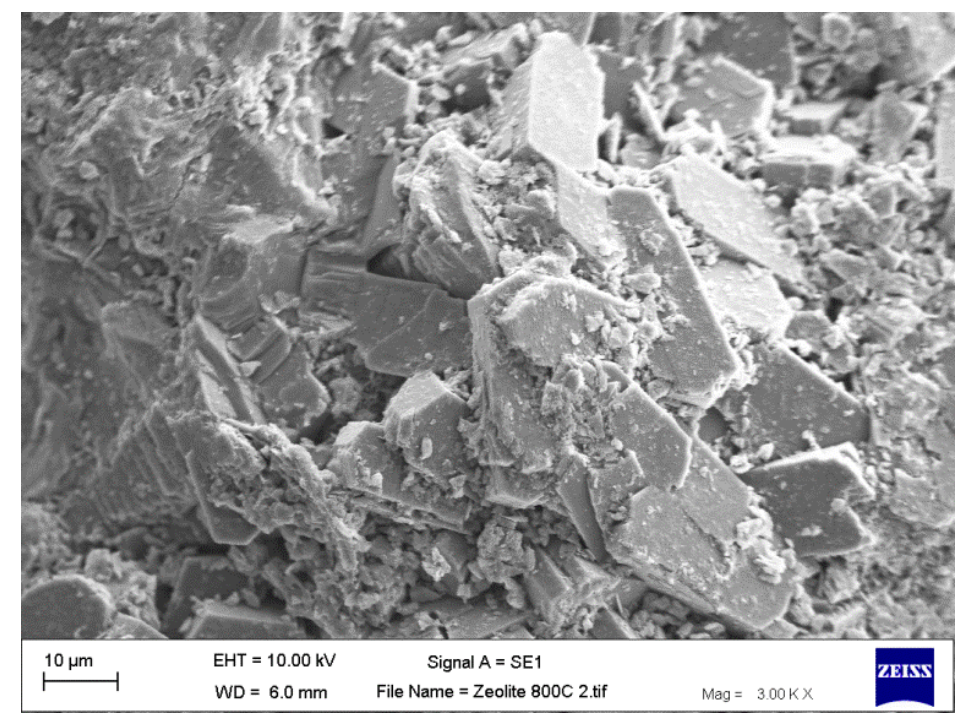

Fig. 4. SEM microstructure of clinoptilolite showing the collapse of the structure of clinoptilolite due to thermal treatment at $600^{\circ} \mathrm{C}$, at a magnification of $3000 \mathrm{x}$.

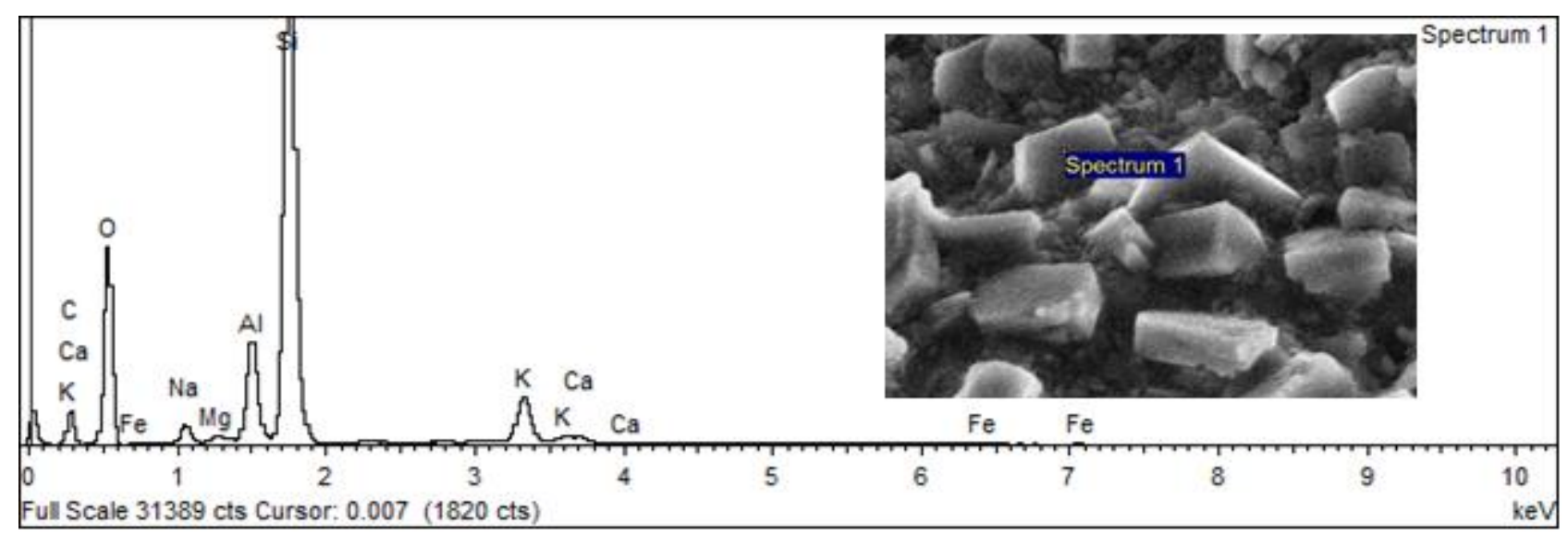

Fig. Error! No text of specified style in document.. EDS analysis showing the elemental composition and the scanned image for clinoptilolite. 


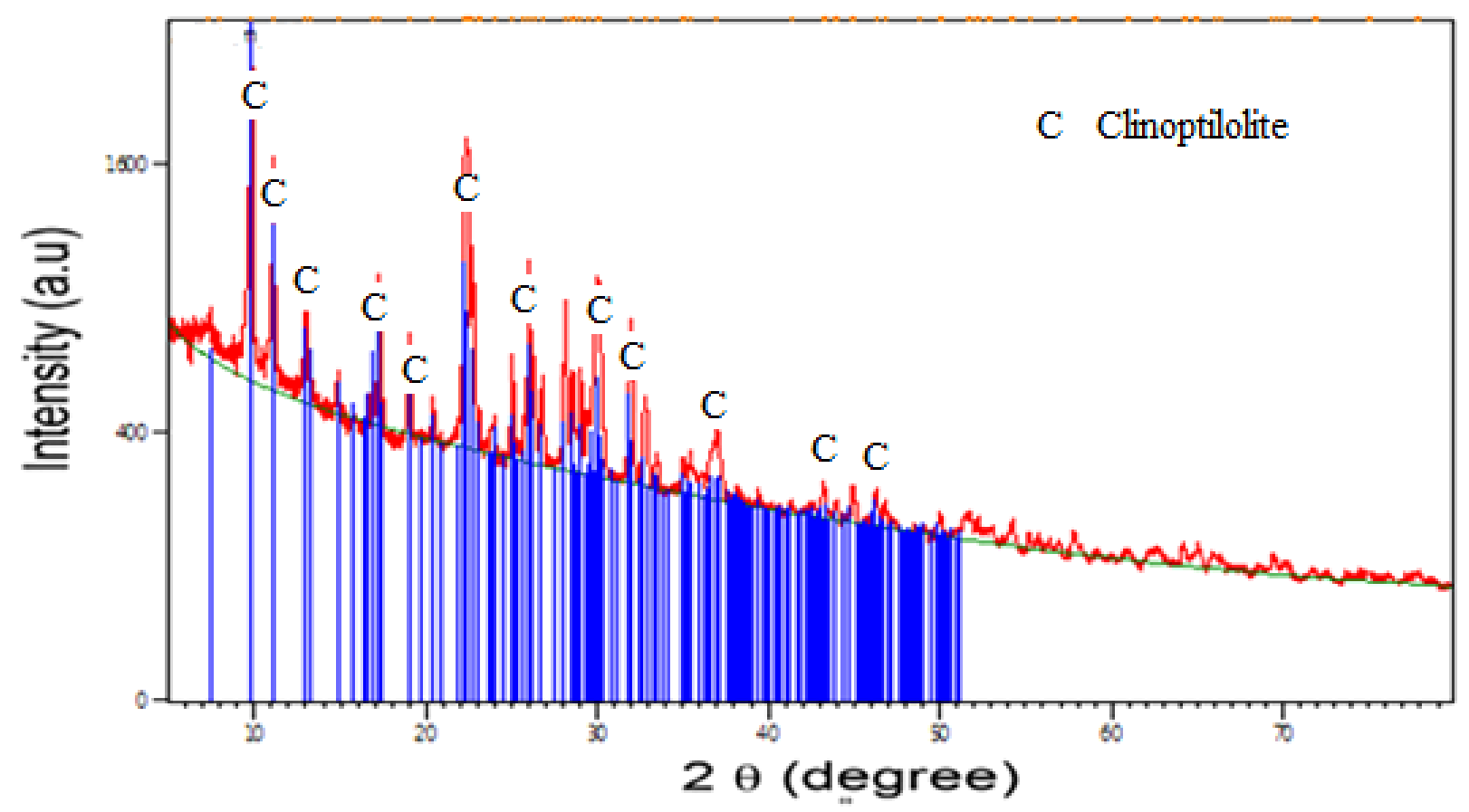

Fig.6. XRD analysis showing the mineralogical analysis of Clinoptilolite.

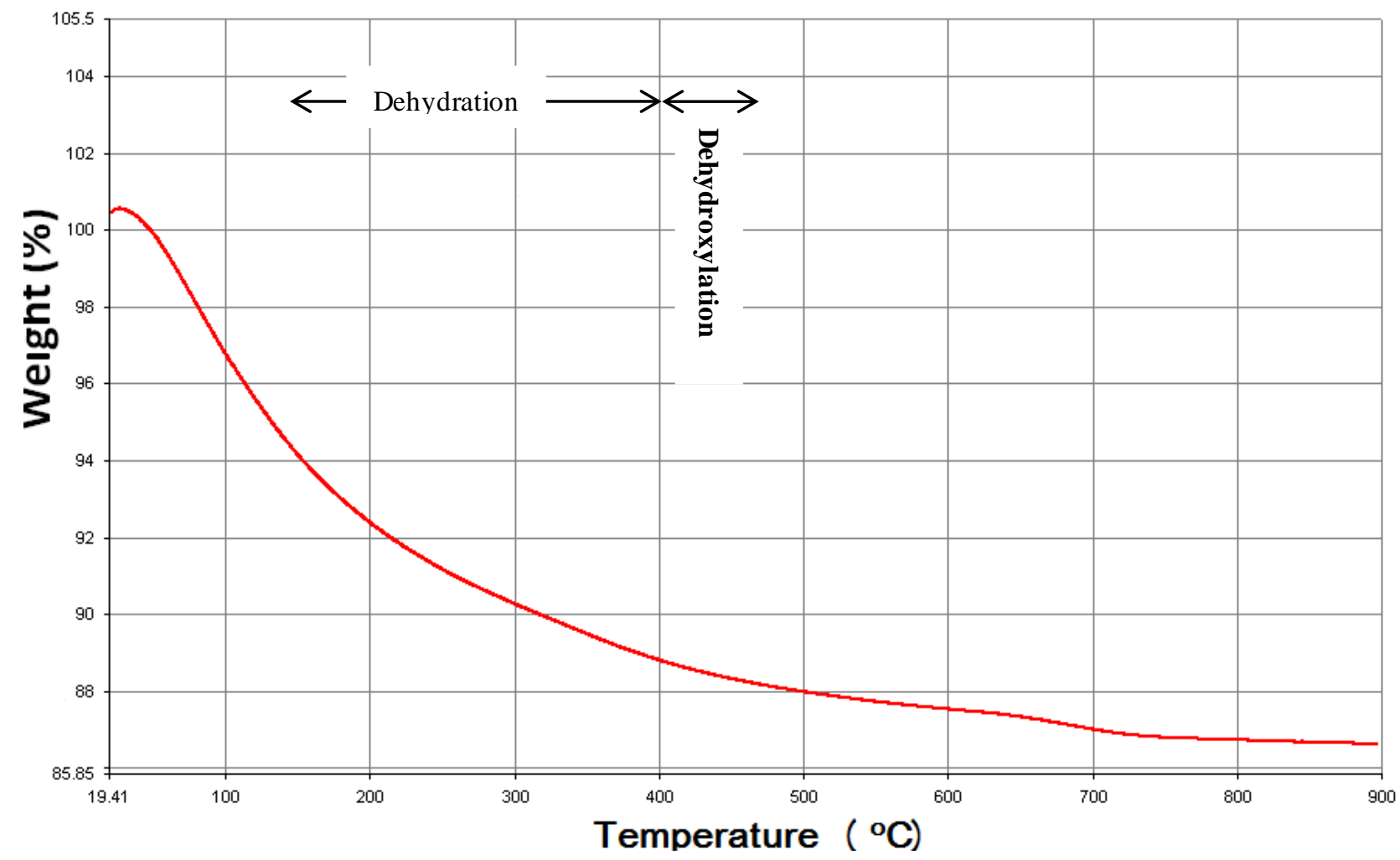

Fig. 7. Shows the loss of mass of clinoptilolite by thermogravimetric analysis (TGA) which show curves between $20-900^{\circ} \mathrm{C}$. 


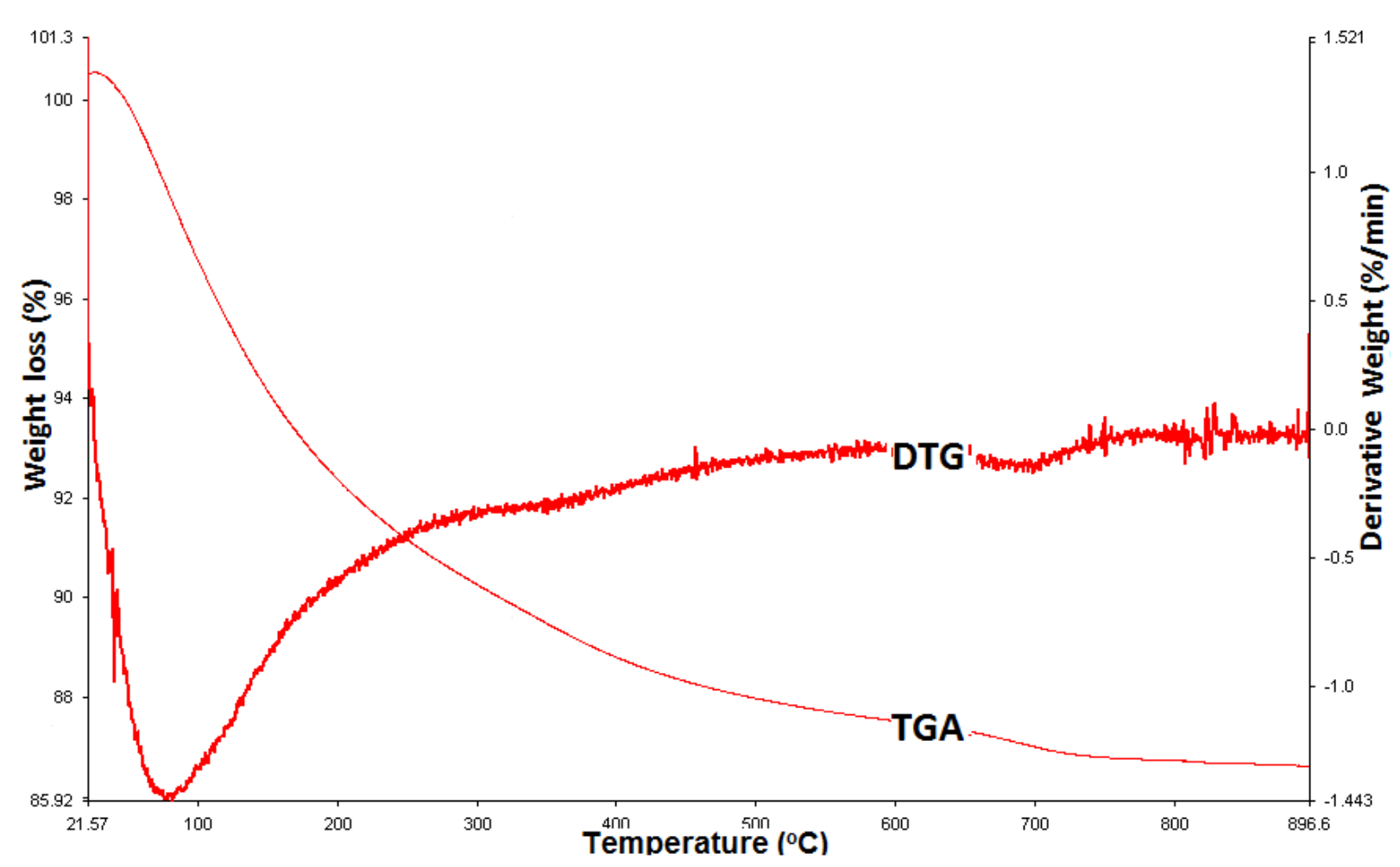

Fig. 8. Thermogravimetric analysis (TGA/DTG) of clinoptilolite between $20-900^{\circ} \mathrm{C}$.

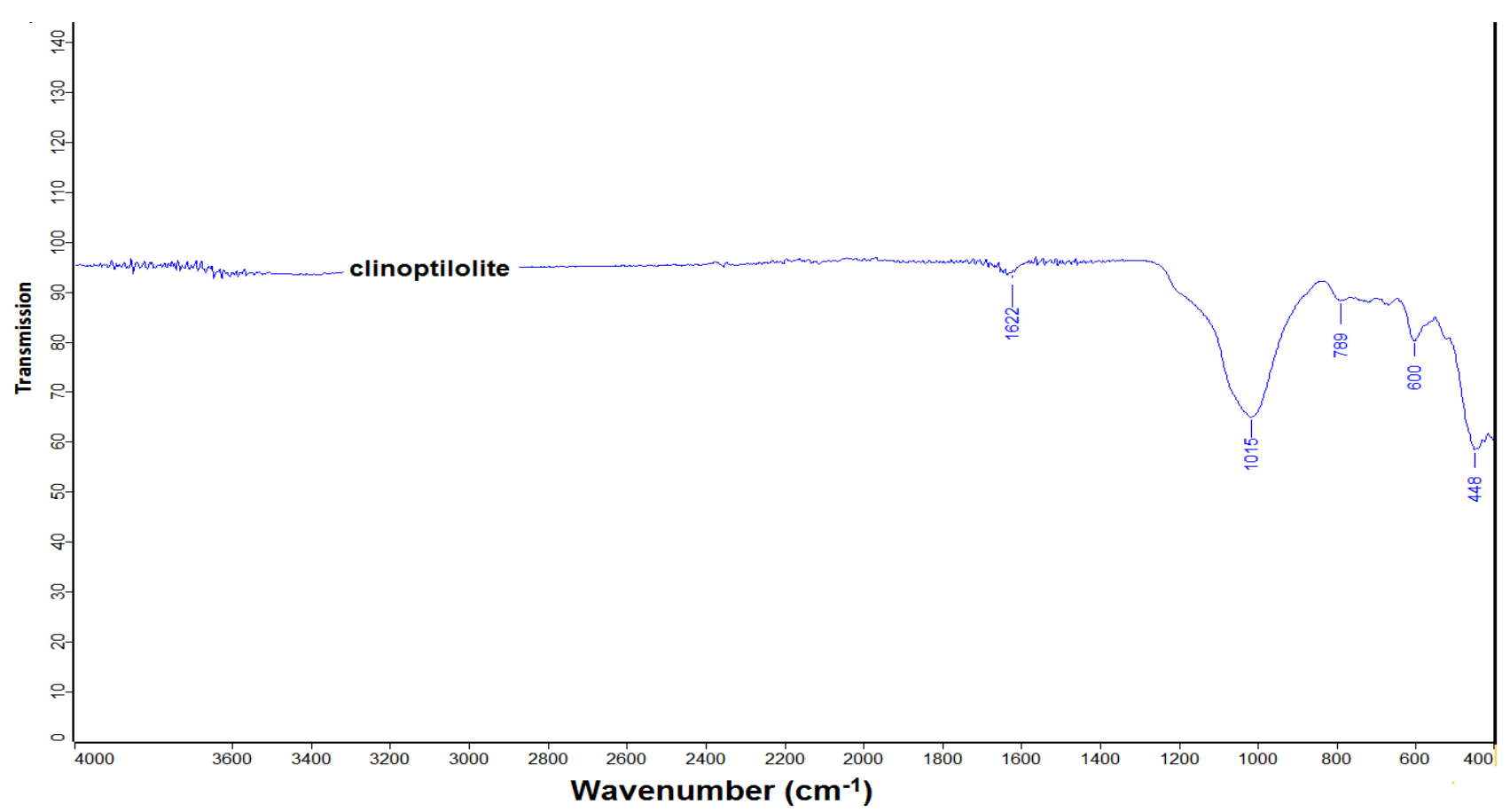

Fig.9. Shows the FT-IR spectra analysis of the as received clinoptilolite. 


\section{$\mathrm{Cu}$}

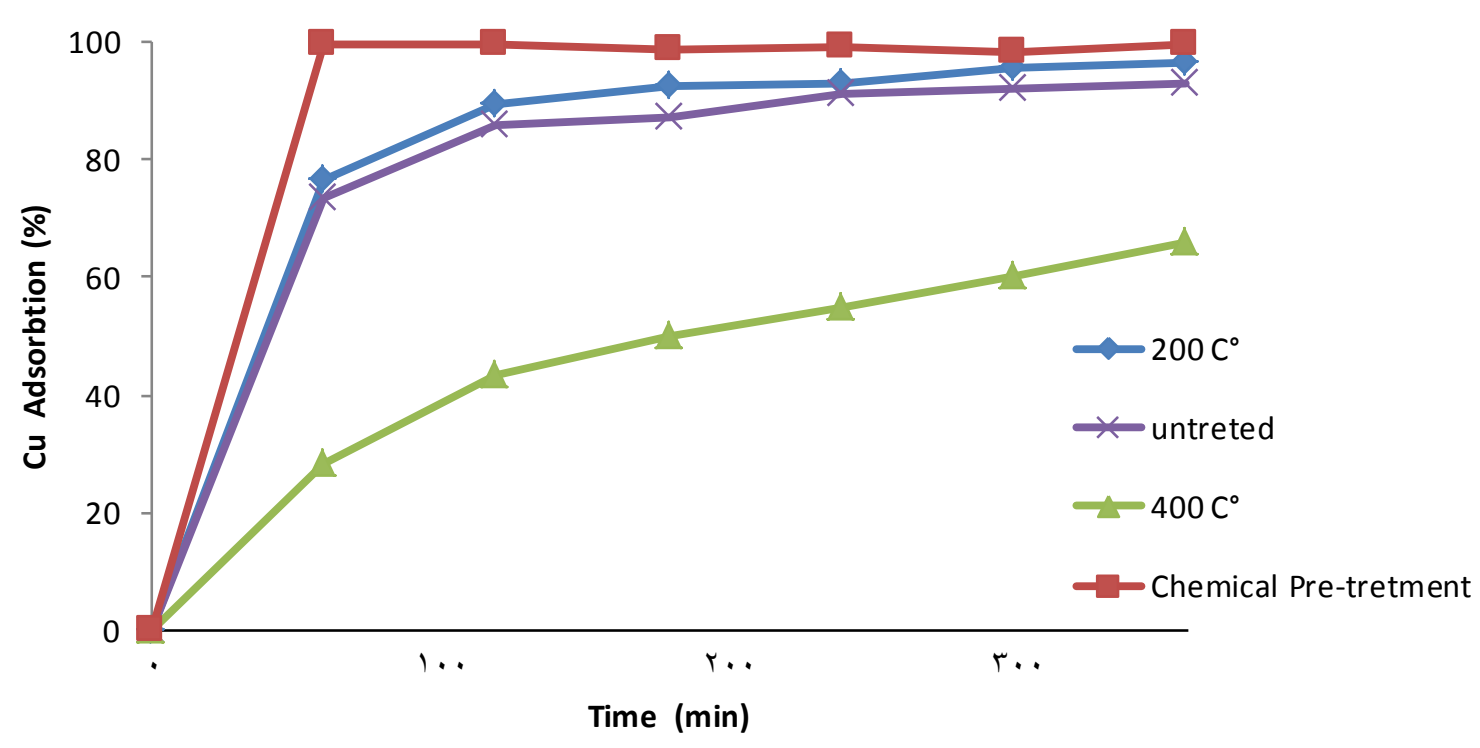

Fe

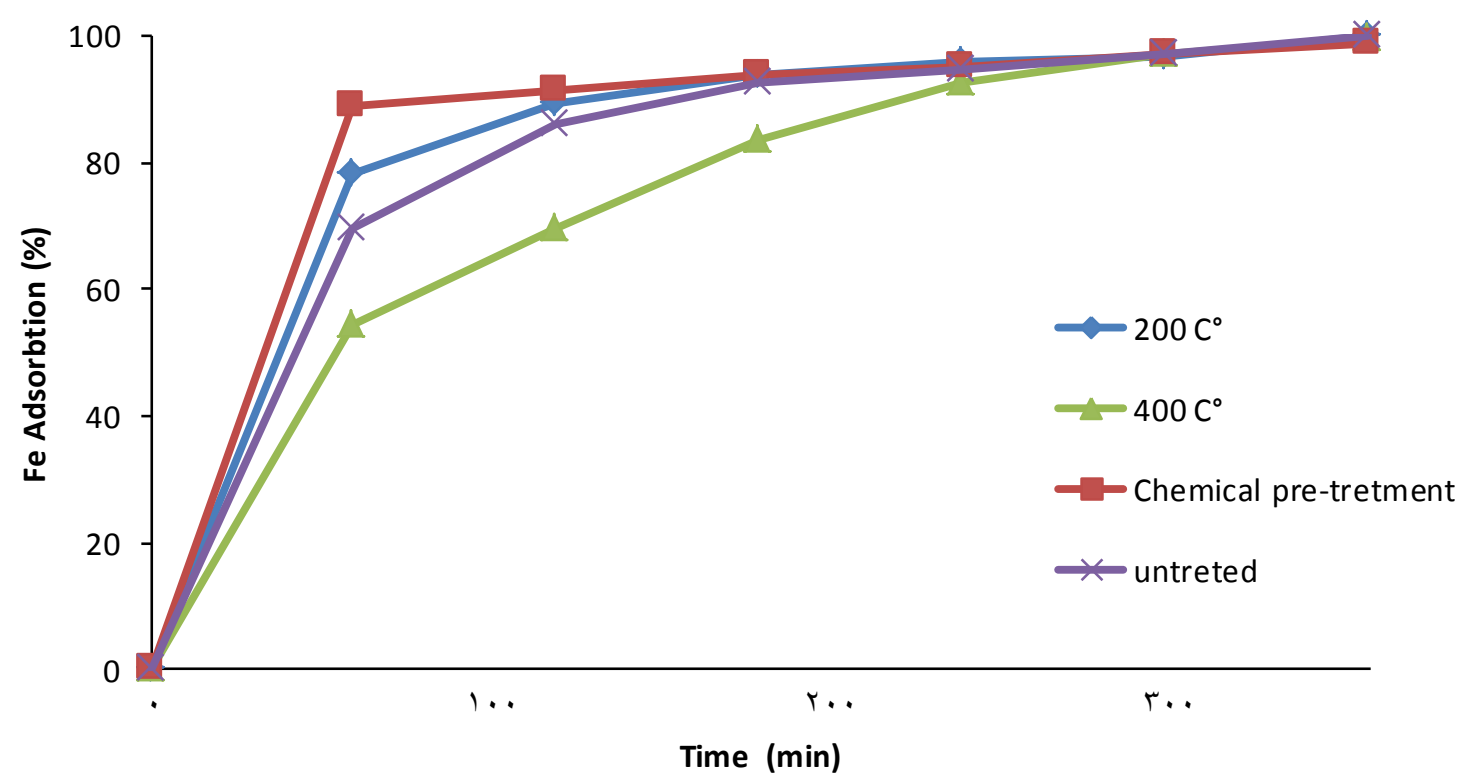




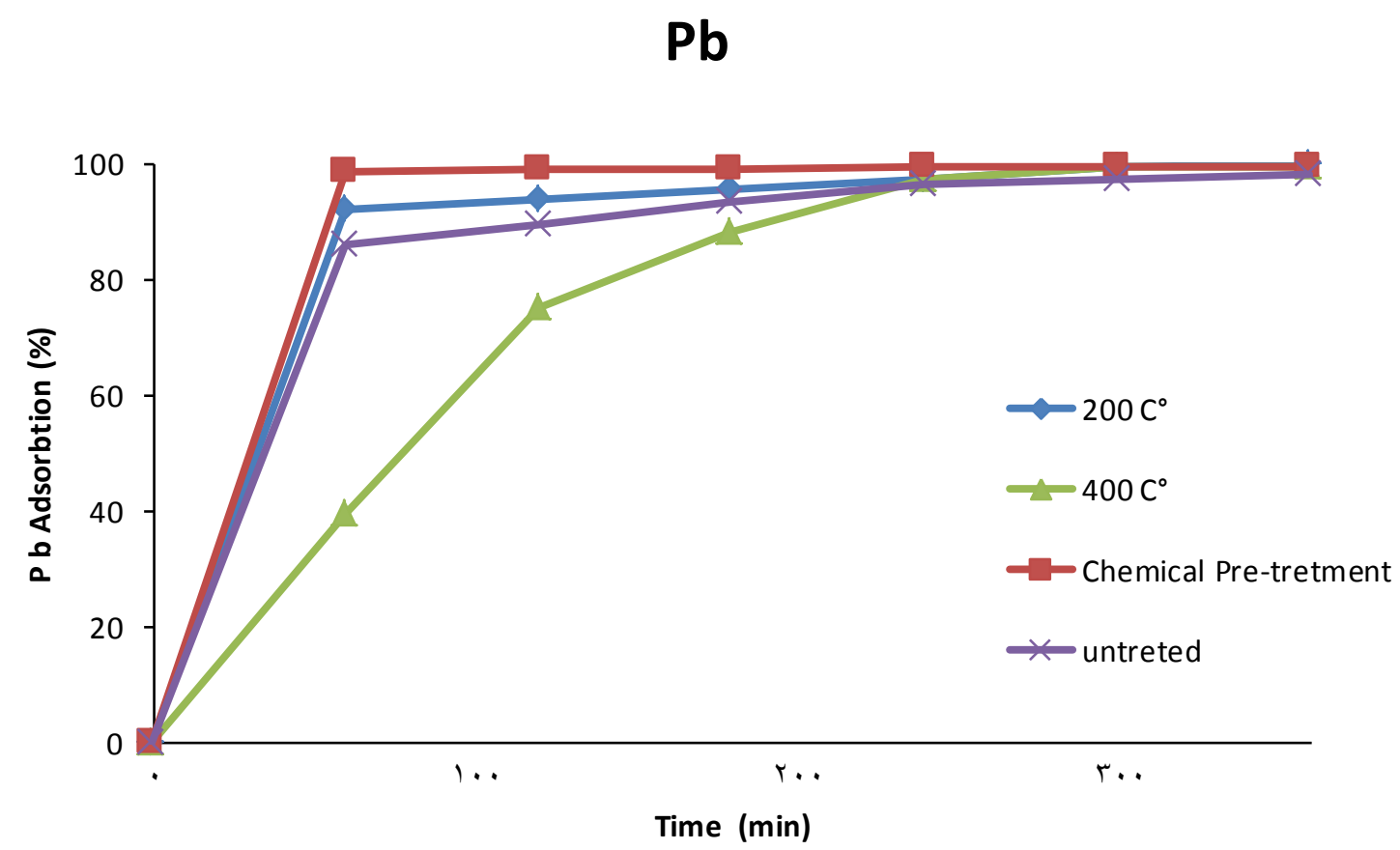

Zn

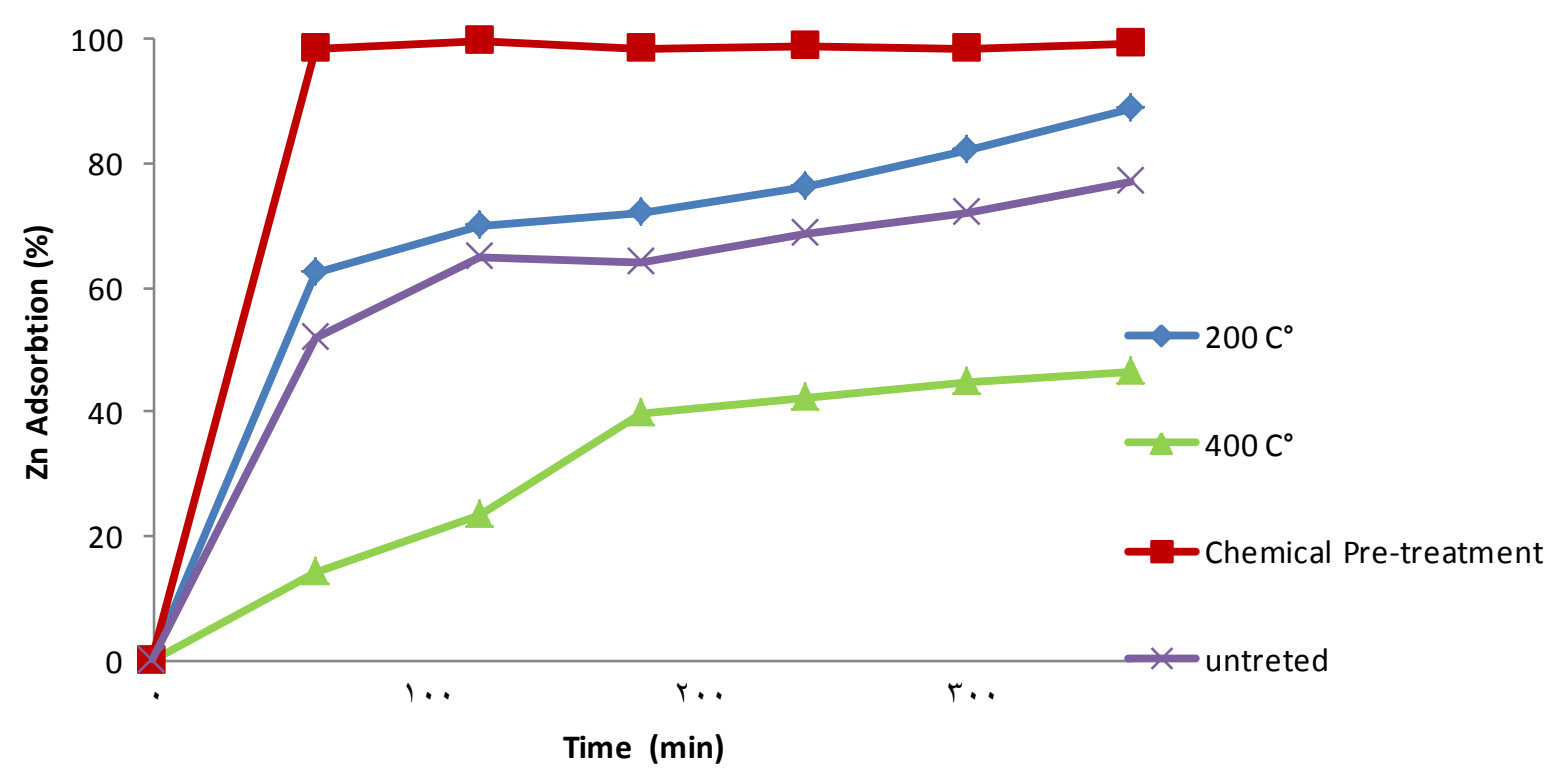

Fig.10. Shows the comparison of un-treated and treated clinoptilolite. 